\title{
Trends in reporting of mechanisms and incidence of hip injuries in males playing minor ice hockey in Canada: a cross-sectional study
}

This article was published in the following Dove Press journal:

Open Access Journal of Sports Medicine

19 June 2014

Number of times this article has been viewed

\author{
Olufemi R Ayeni' \\ Marcin Kowalczuk' \\ Jordan Farag' \\ Forough Farrokhyar ${ }^{1,2}$ \\ Raymond Chu' \\ Asheesh Bedi ${ }^{3}$ \\ Kevin Willits ${ }^{4}$ \\ Mohit Bhandari ${ }^{1,2}$ \\ 'Division of Orthopaedic Surgery, \\ Department of Surgery, ${ }^{2}$ Department \\ of Clinical Epidemiology and \\ Biostatistics, McMaster University, \\ Hamilton, ON, Canada; ${ }^{3}$ Department \\ of Orthopaedic Surgery, University \\ of Michigan, Ann Arbor, MI, USA; \\ ${ }^{4}$ Department of Orthopaedic Surgery, \\ University of Western Ontario, \\ London, ON, Canada
}

Correspondence: Olufemi R Ayeni Division of Orthopaedic Surgery, Department of Surgery, Faculty of Health Sciences, McMaster University, 1200 Main Street West, 4EI75, Hamilton, ON, Canada L8S $3 Z 5$

Tel +l $90552 \mid 2100$ ext 73532

Fax + I 905 52I 9992

Email ayenif@mcmaster.ca
Background: There has been a noted increase in the diagnosis and reporting of sporting hip injuries and conditions in the medical literature but reporting at the minor hockey level is unknown. The purpose of this study is to investigate the trend of reporting hip injuries in amateur ice hockey players in Canada with a focus on injury type and mechanism.

Methods: A retrospective review of the Hockey Canada insurance database was performed and data on ice hockey hip injuries reported between January 2005 and June 2011 were collected. The study population included all male hockey players from Peewee (aged 11-12 years) to Senior (aged 20+ years) participating in amateur level competition sanctioned by Hockey Canada Reported cases of ice hockey hip injuries were analyzed according to age, mechanism of injury, and injury subtype. Annual injury reporting rates were determined and using a linear regression analysis trended to determine the change in ice hockey hip injury reporting rate over time.

Results: One hundred and six cases of ice hockey-related hip injuries were reported in total. The majority of injuries (75.5\%) occurred in players aged $15-20$ years playing at the Junior level. Most injuries were caused by a noncontact mechanism (40.6\%) and strains were the most common subtype (50.0\%). From 2005 to 2010, the number of reported hip injuries increased by 5.31 cases per year and the rate of reported hip injury per 1,000 registered players increased by 0.02 cases annually.

Conclusion: Reporting of hip injuries in amateur ice hockey players is increasing. A more accurate injury reporting system is critical for future epidemiologic studies to accurately document the rate and mechanism of hip injury in amateur ice hockey players.

Keywords: amateur ice hockey, hip injury, pelvic injury, mechanism

\section{Introduction}

Minor (amateur) ice hockey is played by over 900,000 children and adolescents in North America (Canada and the USA). ${ }^{1,2}$ Hip flexion and rotation as well as the body contact that commonly occurs during play make the hip prone to injury. An analysis of ice hockey injuries from the 1988-1989 season through to the 2003-2004 season demonstrated that pelvic and hip muscle strains represent $4.5 \%$ of all in-game injuries, and $13.1 \%$ of practice injuries experienced by men playing in the National Collegiate Athletic Association. ${ }^{3}$ A review of injuries incurred by players at the Junior level (age approximately 18 years) worldwide found hip/thigh/groin injuries to represent approximately $11 \%$ of all injuries. ${ }^{4,5}$ Among pediatric and adolescent amateur ice hockey players over a single season (2004-2005), Emery and Meeuwiss noted injury rates in general increased with age and level of play, with hip/thigh/groin constituting approximately $9 \%$ of all injuries reported. ${ }^{6}$ 
Although common, determining the etiology of hip pain in athletes is complex and can pose a diagnostic challenge to clinicians. Soft tissue injuries such as hip flexor and adductor muscle strains are likely most common; however, disease processes such as osteitis pubis or athletic pubalgia can present with hip pain as well. ${ }^{7}$ More recently, femoroacetabular impingement coupled with acetabular labral tears have become more frequently recognized as a source of hip pain in athletes, particularly in ice hockey players. ${ }^{8,9}$ Stull et al have shown that the ice hockey sprint start places the hip in at-risk positions for labral and cartilage damage. ${ }^{10}$

Despite a relatively high prevalence of hip injuries in ice hockey players of older age groups, there are limited epidemiological studies focusing on ice hockey hip-related injuries in the pediatric and adolescent population, who make up the majority of amateur ice hockey participants. The goal of this study is to investigate the trend of reporting hip injuries in amateur ice hockey players in Canada with a focus on injury type and mechanism.

\section{Materials and methods}

The research ethics board at our institution was consulted, but due to the anonymous nature and external source of the data used in this study, formal approval was not required. A request was submitted to Hockey Canada to release data regarding insurance claims received. Anonymous data regarding ice hockey hip injuries from January 2005 until June 2011 for males were obtained and categorized by age group, skill level, and mechanism (Figure 1).

As per Hockey Canada policy, all players, coaches, referees, and selected staff involved with teams participating in Hockey Canada sanctioned events, leagues, or matches are insured under the Hockey Canada National Insurance Program. This program provides coverage if claims are made within 90 days of an incident and provides additional funds if an individual's primary insurer does not cover all associated costs. To make a claim, a standardized form outlining patient demographics, injury location, type, mechanism, exact time of injury, and protective equipment worn at the time of the injury must be completed. This is completed by the injured player or their parent/guardian by filling in appropriate predetermined fields presented as check boxes on the form. A licensed physician must fill out a portion stating the nature of the injury (diagnosis) and prognosis for recovery. In contrast with other sections of the form, the physician must provide a written description of their findings as opposed to

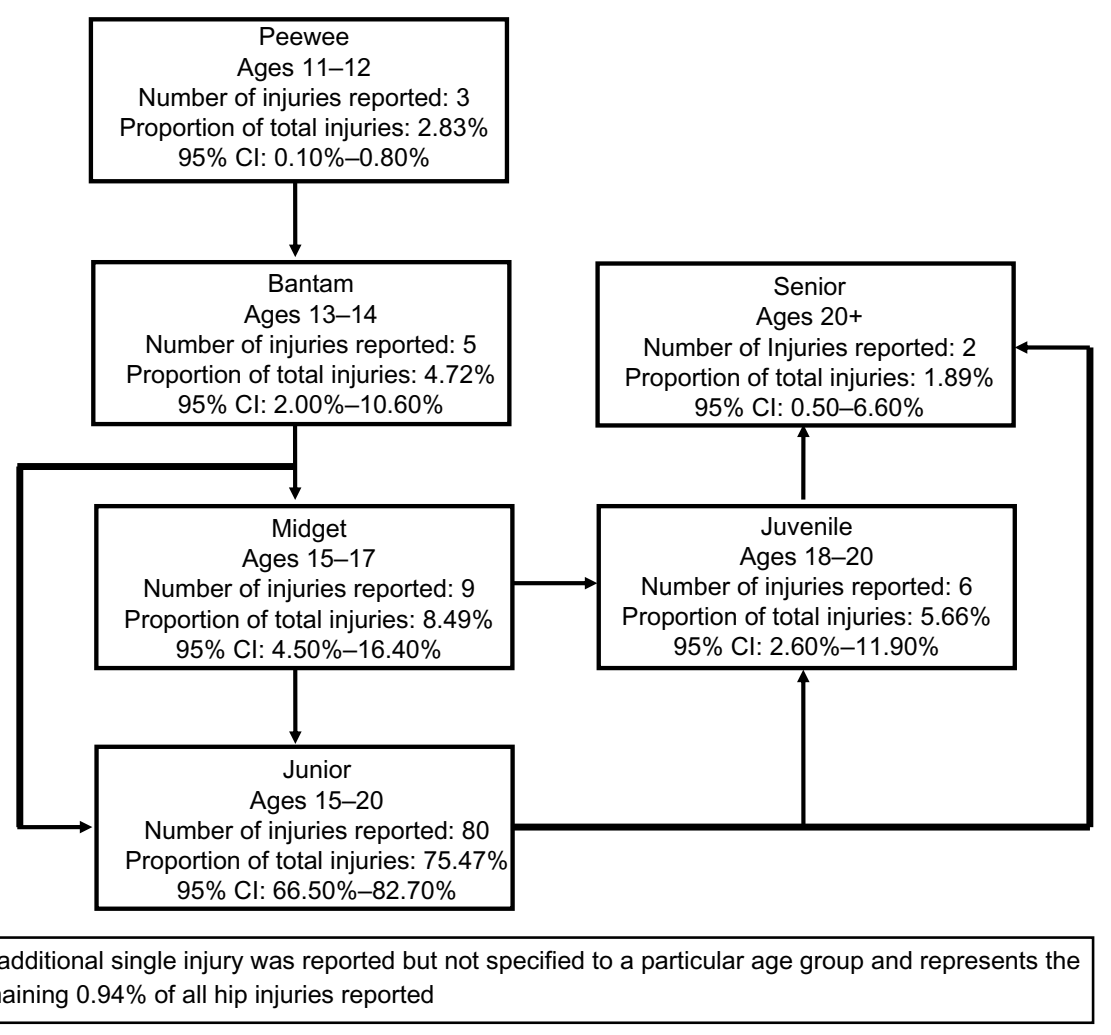

Figure I Age groups in Canadian amateur ice hockey with associated hip injury data.

Notes: Until the age of 15 years, players sequentially move to the next age group. Players aged I5-20 years play either Midget, Junior, or Juvenile level hockey depending on their skill level. The highest skill level is the Junior level. Once over the age of 20 players transition to the Senior level. The number of injuries reported to Hockey Canada in each age group from 2005 until 2010 is shown. The proportion of total reported hip injuries occurring in each age group and associated $95 \%$ confidence intervals are also depicted. 
selecting pre-existing fields listed as checkboxes. Insurance forms must be submitted as hard copies to Hockey Canada and blank forms are available online or through local league offices. All submitted data are coded and stored by Hockey Canada in a central database.

Annual enrollment of amateur ice hockey players in each age group was as ascertained from Hockey Canada's annual reports from 2005 until 2011. ${ }^{11-17}$ Using these data in conjunction with the number of hip injuries reported annually, the annual rate at which hip injuries were reported to Hockey Canada per 1,000 registered participants was calculated with $95 \%$ confidence intervals (CIs). Descriptive statistics are reported. The data were summarized using frequencies and relative frequencies, and were plotted using a bar chart. A Chi-squared goodness of fit test was used to assess the differences in observed frequencies of injuries by year. Frequencies of injuries with their corresponding 95\% CIs are reported. A plotted line graph was used to show the rate of hip injury by year, with a reported coefficient and $R^{2}$ statistic as a measure of explained variation for the regression line generated. Due to the small sample size and insufficient data, a regression analysis to adjust for age and injury factors was not performed. StatsDirect software (Altrincham, Cheshire, UK) and Microsoft Office Excel (Microsoft Corporation, Redmond, WA, USA) were used for all data collection and analysis.

\section{Results}

A total of 106 hip injuries occurring in players from Peewee (aged 11-12 years) to Senior (aged 20+ years) were reported to the Hockey Canada insurance program between 2005 and June 2011 (personal communication from Todd Jackson, 2012, Figure 1). The vast majority (75.5\%; 95\% CI 66.5-82.7) of hip injuries were reported at the Junior level. The Junior level consists of players aged 15-20 years and is considered the highest level of amateur ice hockey in Canada. Less skilled 15-17 year old players play Midget level ice hockey and then either advance to Junior or play at the less skilled Juvenile level, which consists of players aged 18-20 years. Combined, players at the Midget, Junior, and Juvenile levels (all players aged 15-20 years) accounted for 89.7\% (95\% CI 82.4-94.1) of all reported hip injuries.

The most common types of injuries experienced were strains (50.0\%; 95\% CI 40.6-59.4) and contusions (28.3\%; 95\% CI 20.6-37.5), with 53 and 30 instances of each reported, respectively. A single instance of a hip dislocation and a total of five hip fractures were also reported (Table 1). The severity of these fractures is unknown. Noncontact injuries accounted
Table I Injury types reported across all age groups (2005-20I0)

\begin{tabular}{lll}
\hline Injury type & $\begin{array}{l}\text { Number of injuries } \\
(\mathbf{n}=\mathbf{1 0 6})\end{array}$ & $\begin{array}{l}\text { Percentage } \\
\mathbf{( 9 5 \% ~ C l )}\end{array}$ \\
\hline Strain & 53 & $50.0 \%(40.6-59.4)$ \\
Contusion & 30 & $28.3 \%(20.6-37.5)$ \\
Sprain & 7 & $6.6 \%(3.2-13.0)$ \\
Fracture & 5 & $4.7 \%(2.0-10.6)$ \\
Laceration & 5 & $4.7 \%(2.0-10.6)$ \\
No information & 4 & $3.8 \%(1.5-9.3)$ \\
Dislocation & $\mathrm{I}$ & $0.9 \%(0.2-5.2)$ \\
Separation & $\mathrm{I}$ & $0.9 \%(0.2-5.2)$ \\
\hline
\end{tabular}

Abbreviation: $\mathrm{Cl}$, confidence interval.

for $40.6 \%$ (95\% CI 31.7-50.1) of all injuries (Table 2). The remaining contact injuries were most commonly due to collisions involving the boards (17.0\%; 95\% CI 11.0-25.3), other opponents $(16.0 \%$; $95 \%$ CI $10.3-24.2)$, and the ice itself (12.3\%; 95\% CI 7.3-19.9).

The quantity of hip injuries reported annually demonstrates a trend toward increased reporting among amateur players. Reporting peaked in 2010 with 34 injuries however, 2007 also saw a large number of hip injuries reported at 25 . Regression analysis revealed a trend of 5.31 additional hip injuries reported annually between 2005 and 2010 $\left(R^{2}=0.72\right.$, Figure 2$)$.

Cumulative enrollment (Peewee, Midget, Bantam, Juvenile, Junior, and Senior levels) in amateur hockey in Canada between 2005 and 2010 averaged 265,801 participants. Enrollment was lowest in 2007 at 224,380 players and peaked in 2008 with 277,674 players registered (Table 3). Taking into account annual player enrollment, the rate of hip injury reporting was highest in 2007, at 0.129 cases (95\% CI 0.128-0.131) per 1,000 enrolled players (Table 4). Regression analysis revealed the number of hip injuries reported per 1,000 registered players increased from 2005 to 2010 at a rate of 0.02 cases annually $\left(R^{2}=0.67\right.$, Figure 3$)$.

Table 2 Mechanism causing hip injuries across all age groups (2005-2010)

\begin{tabular}{lll}
\hline Injury mechanism & $\begin{array}{l}\text { Number of injuries (\%) } \\
(\mathbf{n = 1 0 6 )}\end{array}$ & $\begin{array}{l}\text { Percentage } \\
(\mathbf{9 5 \%} \mathbf{C I})\end{array}$ \\
\hline Noncontact injury & 43 & $40.6(3 \mathrm{I} .7-50.1)$ \\
Collision with boards & 18 & $17.0(\mathrm{II} .0-25.3)$ \\
Collision with opponent & 17 & $16.0(\mathrm{I} 0.3-24.2)$ \\
Fell on ice & 13 & $12.3(7.3-19.9)$ \\
No data & 6 & $5.7(2.6-1 \mathrm{I} .8)$ \\
Collision on open ice & 4 & $3.8(\mathrm{I} .5-9.3)$ \\
Hit by stick & 3 & $2.8(\mathrm{I} .0-8.0)$ \\
Collision with net & $\mathrm{I}$ & $0.9(0.2-5.2)$ \\
Blindsiding & $\mathrm{I}$ & $0.9(0.2-5.2)$ \\
\hline
\end{tabular}

Abbreviation: $\mathrm{Cl}$, confidence interval. 


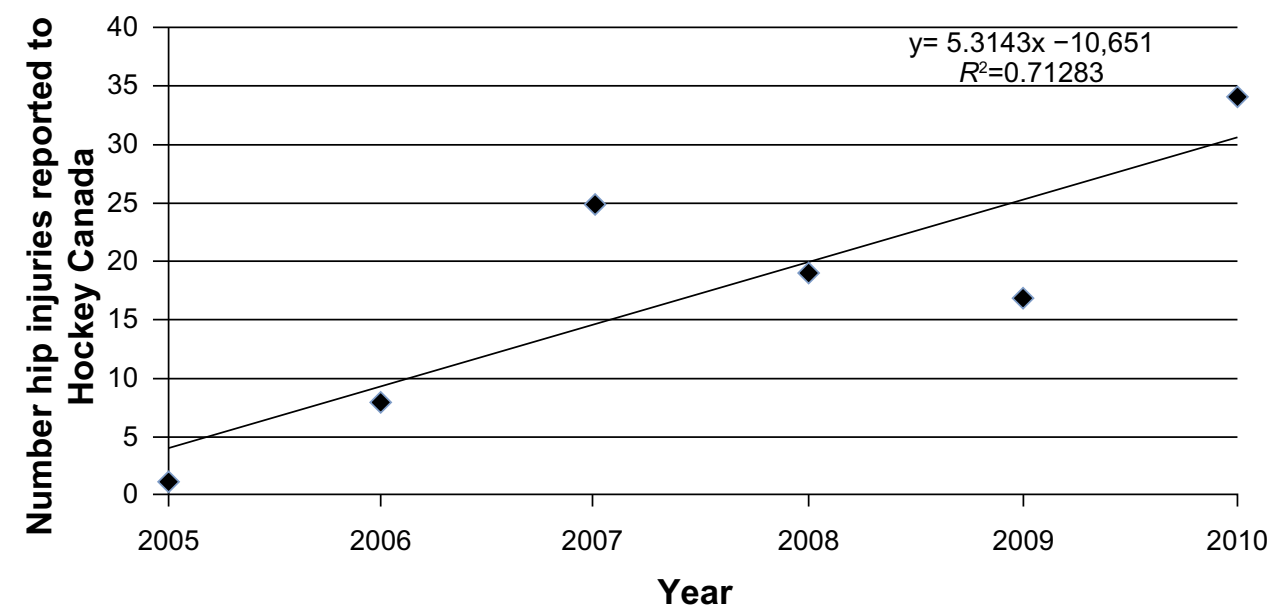

Figure 2 Plotted is the cumulative number of injuries reported to Hockey Canada annually from 2005 until 2010.

Notes: Age groups from Peewee to Senior are represented each year. Regression analysis shows the number of hip injuries being reported is increasing by approximately five cases a year.

\section{Discussion}

Our data suggest that there is an increasing trend to report hip injuries in amateur ice hockey. This trend seems to mirror that of professional leagues in North America and Europe, where hip injuries accounted for $14.7 \%$ of all reported injuries between 1995 and 2000, an increase from the 9.1\% reported from 1960 to $1967 .{ }^{4}$ As players age and compete at higher levels of competition they are more likely to report hip injuries. More injuries were reported at the Junior level than at the Midget or Juvenile levels. Among US amateur ice hockey players, reports have found injuries in general per 1,000 player hours steadily increase from age 9-19 years and are higher among Junior players when compared with their age-matched intercollegiate counterparts who play at a lower level. ${ }^{18}$ Reported injury rates from Canadian amateur minor hockey players mirrored these results as rates increased with player age and level of competition. ${ }^{6}$

With players aged 15-20 years reporting the most injuries, it would seem that player contact is a determining factor in hip injury. However, contact in Canadian amateur ice hockey is first introduced at age 11 years (Peewee)

Table 3 Number of amateur hockey players enrolled according to age group (2005-2010)

\begin{tabular}{|c|c|c|c|c|c|c|}
\hline \multirow{2}{*}{$\begin{array}{l}\text { Age } \\
\text { group }\end{array}$} & \multicolumn{6}{|l|}{ Year } \\
\hline & 2005 & 2006 & 2007 & 2008 & 2009 & 2010 \\
\hline Peewee & 84,889 & 80,412 & 77,338 & 82,023 & 79,610 & 77,674 \\
\hline Bantam & 79,583 & 74,928 & 72,354 & 78,505 & $76,54 I$ & 72,589 \\
\hline Midget & 79,106 & 77,708 & 72,969 & 83,920 & 79,352 & 77,453 \\
\hline Juvenile & 7,447 & 4,038 & 4,000 & 6,664 & 8,608 & 7,751 \\
\hline Junior & 14,973 & 16,028 & $|5,36|$ & 18,290 & $|7,76|$ & 19,435 \\
\hline Senior & 8,373 & 8,043 & 7,358 & 8,272 & 7,73I & 7,720 \\
\hline Total & 274,37 I & 261,157 & 249,380 & 277,674 & 269,603 & 262,622 \\
\hline
\end{tabular}

and the data show noncontact mechanisms to account for approximately $40 \%$ of hip injuries. Agel et al report similar observations, citing that most hip/groin injuries in men playing National Collegiate Athletic Association ice hockey are also sustained via a noncontact mechanism. ${ }^{3}$

To our knowledge, there are no studies that fully address why noncontact injuries of the hip are more common in older players who play at higher levels of competition. Skating biomechanics and muscle fatigue are possible explanations for the observed trends. At higher levels, game play is faster and players are frequently in competition or training all year round. The repetitive forces applied to the hip may predispose to injury. Using a rabbit model, Mair et al showed that fatigued muscles are able to absorb less energy before reaching the degree of stretch associated with injury. ${ }^{19}$ Upjohn et al have shown that elite skaters, when compared with their novice counterparts, have longer stride lengths due to a greater range of motion at the hip, knee, and ankle. ${ }^{20} \mathrm{In}$ contrast, Chang et al state that elite skaters do not necessarily increase hip range of motion but rather impart a greater impulse against the ice surface with each stride to attain high

Table 4 Rate of hip injury reporting per I,000 registered players, with age groups from Peewee to Senior represented each year

\begin{tabular}{lll}
\hline Year & $\begin{array}{l}\text { Hip injuries reported per } \\
\text { I,000 registered players }(\mathbf{n})\end{array}$ & $\mathbf{9 5 \%} \mathbf{C l}$ \\
\hline 2005 & 0.003 & $(0.003-0.004)$ \\
2006 & 0.030 & $(0.029-0.03 \mathrm{I})$ \\
2007 & 0.100 & $(0.099-0.10 \mathrm{I})$ \\
2008 & 0.068 & $(0.063-0.065)$ \\
2009 & 0.063 & $(0.062-0.064)$ \\
2010 & 0.129 & $(0.128-0.13 \mathrm{I})$ \\
\hline
\end{tabular}

Abbreviation: $\mathrm{Cl}$, confidence interval. 


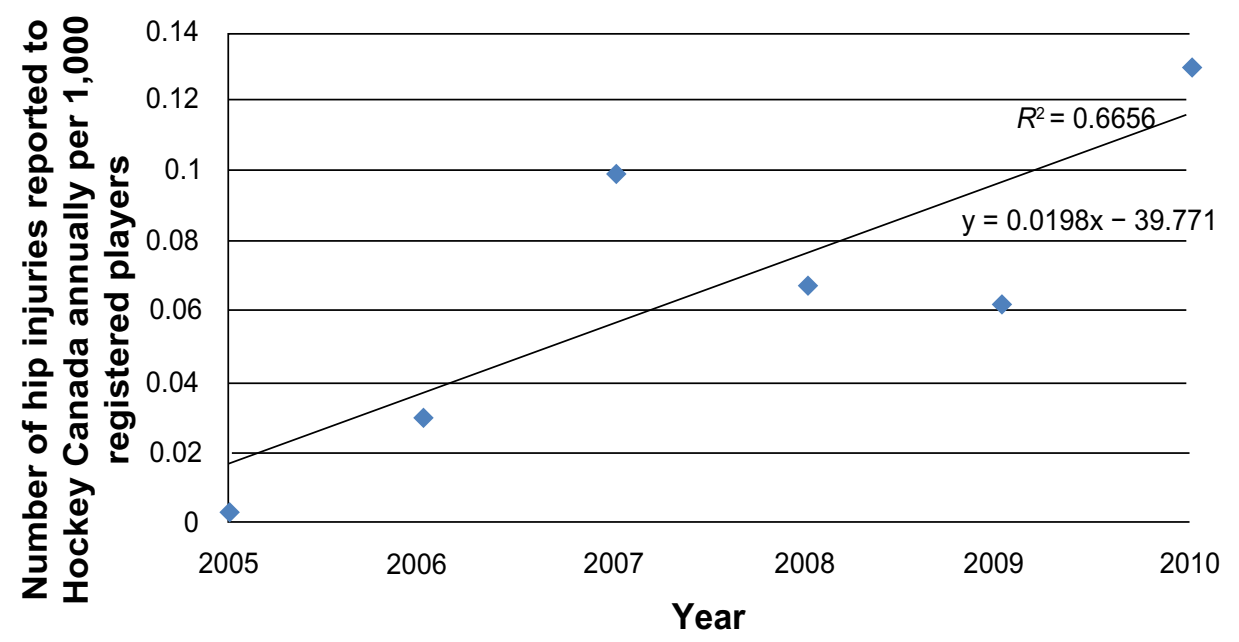

Figure 3 Plotted is the rate of hip injury reporting to Hockey Canada per 1,000 registered participants annually from 2005 to 2010.

Notes: Age groups from Peewee to Senior are represented each year. Regression analysis yields an annually increasing rate of reporting of 0.02 cases a year.

speeds. ${ }^{21}$ Despite these conflicting theories, these studies show that there are greater forces stressing the hip's bony anatomy and soft tissue structures during skating. These forces increase as players become heavier and stronger, potentially leading to injury.

The last decade has seen rapid development in our understanding of hip conditions such as femoroacetabular impingement. It is a known source of hip pain in the young adult and a potential precursor to osteoarthritis. ${ }^{22}$ In a recent study, Siebenrock et al used basketball players as a model and found that the prevalence of CAM-type deformities was much higher among individuals who compete in high level athletics in their adolescent years. ${ }^{23}$ Agricola et al studied soccer players in particular and found CAM-type deformities to develop as early as 13 years of age and to be much more prevalent when compared with age-matched nonathletic controls. ${ }^{24}$ Hockey sprint starts place the hip in an at-risk position of external rotation and abduction in the push-off phase and internal rotation and flexion at the end of a skating stride. ${ }^{10}$ These two positions can lead to abnormal impingement of the femoral neck against the acetabulum, leading to damage of intra-articular structures. The misdiagnosis of femoroacetabular impingement as hip strains is quite common. ${ }^{25}$ As amateur ice hockey players get older, noncontact hip injuries reported in our data set may represent cases of newly symptomatic femoroacetabular impingement.

To our knowledge, this is the first paper to analyze trends in hip injury reporting among amateur ice hockey athletes using a national database. It is also unique that both trends in injury pattern and mechanism of injury were extracted from this national database. Using this database ensures that all injuries were reported by physicians using standardized reporting forms. This adds credibility to the quality of the data pertaining to diagnosis.

This report may be limited by the quality of information present in the database, such as missing or incomplete data. Injury reports in all cases were made retrospectively, and some players may not have sought medical attention for less serious injuries. These factors coupled with players themselves identifying the mechanism of injury on insurance forms may introduce recall bias. Furthermore, the time interval between injury and claim submission would influence recall bias. Participants must submit claims within 90 days, but data on the exact time interval between injury and claim submission was unavailable. Although all medical diagnoses on insurance claims are filled out by licensed physicians, misdiagnosis is always a possibility. Data on how and what type of physician made a particular diagnosis including what imaging modalities if any were used was not made available. Given their vague history and variable presentation, misdiagnosis if present, was most likely with reported hip strains and contusions. Also, in the setting of more serious concurrent injury, such as a severe concussion, hip injuries may not be reported or missed altogether. Finally, the completeness of the dataset may have depended on the severity of the injury as reporting occurred in cases where compensation is sought for injury treatment. Thus, more severe injuries may be overrepresented in the reviewed data.

Given these considerations, our data likely underrepresents the number of hip injuries in ice hockey. Data on hip injury in younger age groups, along with access to the exact details of each insurance claim made, would allow for more accurate prevalence estimates. In addition, this data set did not include females and could not account 
for confounders such as player socioeconomic status and extent of individual team medical staff expertise. Higher level teams composed of older players are more likely to have larger and more specialized dedicated medical staff personnel that are more likely to file insurance claims. Players from lower income households may also be more likely to file insurance claims to help offset the financial burden of injuries sustained. The data are also difficult to interpret because data on the total number of injuries reported to the Hockey Canada insurance program was not made available. This made it impossible to conclude whether the number of hip injuries reported had increased relative to the total number of injuries reported. Previous studies have shown that injury reporting rates increase with player age but, to our knowledge, no studies have examined how injury rates in minor hockey have changed over time. ${ }^{6}$

Although an annual rate of hip injury reporting was determined in this study, it cannot be used as a means to estimate the incidence of ice hockey hip injury. Due to the small size of the injured sample, the study is not powered to make a definitive conclusion about injury rates. To have meaningful precision to detect linear trends in the incidence of hip injury in amateur athletes over time, 162 reported hip injury cases would be required from the sampling database for a one-sided test with an alpha error of 0.05 and a beta error of 0.1 (90\% power). ${ }^{26}$

The rising trend in hip injury reporting potentially represents a growing number of hip injuries among amateur ice hockey players in Canada or improved recognition and reporting of such injuries. In this analysis, hip injuries occur more often in older players (aged 15-20 years) at higher levels of competition (Junior) and are usually the result of noncontact mechanisms. Future studies surrounding hip injury in ice hockey players would benefit from a more standardized database which mandates injury reporting regardless of severity. With more complete prospectively collected data, the epidemiology of ice hockey hip injury in amateur athletes can be better understood and used to develop a program that focuses on injury prevention.

\section{Disclosure}

The authors report no conflicts of interest in this work.

\section{References}

1. Hockey Canada. 2012 Annual Report. Ottawa, ON, Canada: Hockey Canada; 2013. Available from: http://cdn.agilitycms.com/hockey-canada/ Corporate/About/Downloads/2012_annual_report_e.pdf. Accessed July 11, 2013.
2. USA Hockey. 2010/2011 Annual Report. Colorado Springs, CO, USA: USA Hockey; 2011. Available from: http://wwa.usahockey.com/ uploadedFiles/USAHockey/Menu_About_USA_Hockey/2011\%20 USAH\%20Annual\%20Report_WEB.pdf. Accessed July 11, 2013.

3. Agel J, Dompier TP, Dick R, Marshall SM. Descriptive epidemiology of collegiate men's ice hockey injuries: National Collegiate Athletic Association Injury Surveillance System, 1988-1989 through 2003-2004. J Athl Train. 2007;42(2):241-248.

4. Azuelos YH, Pearsall DJ, Turcotte R, Montgomery D. A review of ice hockey injuries: location, diagnosis, and mechanism. In: Pearsall DJ, Ashare AB, editors. Safety in Ice Hockey. Fourth Volume. West Conshohocken, PA, USA: ATSM International; 2004.

5. Stuart MJ, Smith A. Injuries in Junior A ice hockey. A three-year prospective study. Am J Sports Med. 1995;23(4):458-461.

6. Emery CA, Meeuwisse WH. Injury rates, risk factors, and mechanisms of injury in minor hockey. Am J Sports Med. 2006;34(12):1960-1969.

7. Garvey JF, Hazard H. Sports hernia or groin disruption injury? Chronic athletic groin pain: a retrospective study of 100 patients with long-term follow-up. Hernia. October 12, 2013. [Epub ahead of print.]

8. Ayeni OR, Banga K, Bhandari M, et al. Femoroacetabular impingement in elite ice hockey players. Knee Surg Sports Traumatol Arthrosc. 2014;22(4):920-925.

9. Philippon MJ, Ho CP, Briggs KK, Stull J, LaPrade RF. Prevalence of increased alpha angles as a measure of Cam-type femoroacetabular impingement in youth ice hockey players. Am J Sports Med. 2013;41(6): 1357-1362.

10. Stull JD, Philippon MJ, LaPrade RF. "At-risk" positioning and hip biomechanics of the Peewee ice hockey sprint start. Am J Sports Med. 2011;39 Suppl:29S-35S.

11. Hockey Canada. 2005 Annual Report. Ottawa, ON, Canada: Hockey Canada; 2013. Available from: http://cdn.agilitycms.com/hockeycanada/Corporate/About/Downloads/2005_annual_report.pdf. Accessed July 11, 2013.

12. Hockey Canada. 2006 Annual Report. Ottawa, ON, USA: Hockey Canada; 2013. Available from: http://cdn.agilitycms.com/hockeycanada/Corporate/About/Downloads/2006_annual_report.pdf. Accessed July 11, 2013.

13. Hockey Canada. 2007 Annual Report. Ottawa, ON, USA: Hockey Canada; 2013. Available from: http://cdn.agilitycms.com/hockeycanada/Corporate/About/Downloads/2007_annual_report.pdf. Accessed July 11, 2013.

14. Hockey Canada. 2008 Annual Report. Ottawa, ON, USA: Hockey Canada; 2013. Available from: http://cdn.agilitycms.com/hockeycanada/Corporate/About/Downloads/2008_annual_report.pdf. Accessed July 11, 2013.

15. Hockey Canada. 2009 Annual Report. Ottawa, ON, USA: Hockey Canada; 2013. Available from: http://cdn.agilitycms.com/hockeycanada/Corporate/About/Downloads/2009_annual_report.pdf. Accessed July 11, 2013.

16. Hockey Canada. 2010 Annual Report. Ottawa, ON, USA: Hockey Canada; 2013. Available from: http://cdn.agilitycms.com/hockeycanada/Corporate/About/Downloads/2010_annual_report.pdf. Accessed July 11, 2013.

17. Hockey Canada. 2011 Annual Report. Ottawa, ON, USA: Hockey Canada; 2013. Available from: http://cdn.agilitycms.com/hockeycanada/Corporate/About/Downloads/2011_annual_report_e.pdf. Accessed July 11, 2013.

18. Smith AM, Stuart MJ, Wiese-Bjornstal DM, Gunnon C. Predictors of injury in ice hockey players. Am J Sports Med. 1997;25(4):500-507.

19. Mair SD, Seaber AV, Glisson RR, Garrett WE Jr. The role of fatigue in susceptibility to acute muscle strain injury. Am J Sports Med. 1996;24(2):137-143.

20. Upjohn T, Turcotte R, David JP, Loh J. Three-dimensional kinematics of the lower limbs during forward ice hockey skating. Sports Biomech. 2008;7(2):206-221.

21. Chang R, Turcotte R, Pearsall D. Hip adductor muscle function in forward skating. Sports Biomech. 2009;8(3):212-222. 
22. Sankar WN, Nevitt M, Parvizi J, Felson DT, Agricola R, Leunig M. Femoroacetabular impingement: defining the condition and its role in the pathophysiology of osteoarthritis. J Am Acad Orthop Surg. 2013; 21 Suppl 1:S7-S15.

23. Siebenrock K, Ferner F, Noble P, Santore RF, Werlen S, Mamisch TC. The Cam-type deformity of the proximal femur arises in childhood in response to vigorous sporting activity. Clin Orthop Relat Res. 2011;469(11):3229-3240.
24. Agricola R, Bessems J, Ginai A, et al. The development of Cam-type deformity in adolescent and young male soccer players. Am J Sports Med. 2012;40(5):1099-1106.

25. Keogh MJ, Batt ME. A review of femoroacetabular impingement in athletes. Sports Med. 2008;38(10):863-878.

26. Nam J. A simple approximation for calculating sample sizes for detecting linear trend in proportions. Biometrics. 1987;43(3):701-705.

\section{Publish your work in this journal}

Open Access Journal of Sports Medicine is an international, peer-reviewed, open access journal publishing original research, reports, reviews and commentaries on all areas of sports medicine. The manuscript management system is completely online and includes a very quick and fair peer-review system.
Visit http://www.dovepress.com/testimonials.php to read real quotes from published authors. 